\title{
Developing Legacy: Health Planning in the Host City of Porto Alegre for the 2014 Football World Cup
}

\author{
Regina Rigatto Witt, RN, MPH, PhD; ${ }^{1}$ Mauro Kruter Kotlhar, $\mathrm{CE} ;{ }^{2}$ Marilise Oliveira Mesquita, \\ MS, PhD ; ${ }^{1}$ Maria Alice Dias da Silva Lima, RN, MS, PhD; ${ }^{1}$ Sandra Mara Marin, RN, MN; ${ }^{3}$ \\ Carolina Baltar Day, RN, MN; ${ }^{4}$ Andrea Goncalves Bandeira, RN, MN; ${ }^{5}$ Alison Hutton, RN, MD, $\mathrm{PhD}^{6}$
}

1. Universidade Federal do Rio Grande do Sul, Porto Alegre, Brazil

2. Health Surveillance State Center, Health Secretariat of the State of Rio Grande do Sul, Porto Alegre, Brazil

3. Universidade Estadual de Santa Catarina, Chapecó, Santa Catarina, Brazil

4. Grupo Hospitalar Conceição, Porto Alegre, Rio Grande do Sul, Brazil

5. Pontifícia Universidade Católica do Rio Grande do Sul, Brazil

6. Flinders University, Adelaide, Australia

Correspondence:

Regina Rigatto Witt, RN, MPH, PhD

Escola de Enfermagem UFRGS

rua São Manoel 963 CEP 90620-110 POA RS

E-mail: regina.witt@ufrgs.br

Conflicts of interest: none

Keywords: health care systems; legacy; massgathering health; public health surveillance; World Cup

Abbreviations:

FIFA: Federation Internationale de Football Association

WHO: World Health Organization

Received: December 16, 2014

Revised: April 29, 2015

Accepted: May 18, 2015

Online publication: October 21, 2015

doi:10.1017/S1049023X15005233
Abstract

Aim: To describe the process adopted to identify, classify, and evaluate legacy of health care planning in the host city of Porto Alegre for the Football World Cup 2014.

Background: There is an emerging interest in the need to demonstrate a sustainable health legacy from mass gatherings investments. Leaving a public health legacy for future host cities and countries is now an important part of planning for these events.

Process: The Ministry of Sports initiated and coordinated the development of projects in the host cities to identify actions, projects, and constructions to be developed to prepare for the World Cup. In Porto Alegre, a common structure was developed by the coordinating team to instruct legacy identification, classification, and evaluation. This structure was based on international documentary analysis (including official reports, policy documents, and web-based resources) and direct communication with recognized experts in the field. Findings and Interpretation: Sixteen total legacies were identified for health surveillance (5) and health services (11). They were classified according to the strategic area, organizations involved, dimension, typology, planned or unplanned, tangible or intangible, territorial coverage, and situation prior to the World Cup. Possible impacts were then assessed as positive, negative, and potentiating, and mitigating actions were indicated.

Conclusions: The project allowed the identification, classification, and development of health legacy, including risk analysis, surveillance, mitigation measures, and provision of emergency medical care. Although the project intended the development of indicators to measure the identified legacies, evaluation was not possible at the time of publication due to time.

Witt RR, Kotlhar MK, Mesquita MO, Lima MADS, Marin SM, Day CB, Bandeira AG, Hutton A. Developing legacy: health planning in the host city of Porto Alegre for the 2014 Football World Cup. Prehosp Disaster Med. 2015;30(6):613-617.

\section{Introduction}

The Federation Internationale de Football Association World Cup in Brazil

The Federation Internationale de Football Association (FIFA; Zurich, Switzerland) World Cup is one of the world's main sporting events and was held in Brazil from June $12^{\text {th }}$ to July $13^{\text {th }}, 2014$. This event attracted one million foreign tourists, from 202 countries, exceeding the expectation of the Brazilian government for this event of only 600,000 tourists.

Such an event can generate patient loads for hospitals and may pose logistical and technical issues for the country. ${ }^{1,2}$ Despite its many challenges, the preparation for a mass gathering can also become an opportunity to promote social and economic development. ${ }^{3}$ Efforts to connect mass gatherings with lasting improvements are known as health legacies. There is an emerging interest in the need to demonstrate a sustainable health legacy from mass gatherings investments. ${ }^{4}$ Leaving a public health legacy for future host cities and countries is now an important part of planning for these events and has been approached successfully in the Beijing ${ }^{5}$ (2008) and London (2012) Olympic Games. ${ }^{4,6}$

Based on the country's previous mass-gathering experience, such as Carnaval and the New Year's Celebration in Rio de Janeiro, the Brazilian Ministry of Health (Brasília-DF) expected a legacy to be left for Brazilians. For the health area, the improvement of 
emergency and surveillance systems and a better integration between health care and security, traffic control, and fire services were expected. This report describes the process adopted to identify, classify, and evaluate legacy of health care planning in the host city of Porto Alegre for the FIFA World Cup 2014.

\section{Background}

A mass gathering is defined as "more than a specified number of persons (which may be as few as 1,000 persons, although much of the available literature describes gatherings exceeding 25,000 persons) at a specific location for a specific purpose (a social function, large public event, or sports competition) for a defined period of time." These gatherings might be planned or unplanned, recurrent or sporadic, and are attended by sufficient numbers of people to potentially strain the planning and response resources of the hosting community, state, or nation. ${ }^{7}$

Mass gatherings the size of the World Cup pose complex challenges to its organizers and require broad expertise, such as crowd management, security, and emergency preparedness. Stampedes and crush injuries are common, the result of inevitable crowding. ${ }^{2}$ Outdoor events are often associated with complications of exposure, dehydration, sunburn, and heat exhaustion., ${ }^{8,9}$ Other health hazards may arise from lack of food hygiene, inadequate waste management, and poor sanitation, ${ }^{9}$ as well as communicable diseases associated with the flow of tourists. Lastly, crowd violence and the potential for terrorist attacks are unpredictable and difficult to mitigate. ${ }^{10}$

This type of mass gathering can affect the country's health care infrastructure and requires a multinational approach to public health. ${ }^{9,11}$ Regardless of the capacity of the health care system of the host nation, mass gatherings require special planning and preparedness efforts within the health system. ${ }^{1,12}$ These components include: disease monitoring and control; environmental and food surveillance; public information and/or health promotion; and Emergency Medical Services. ${ }^{13}$

Mass gatherings can create many possibilities for cities and countries to acquire knowledge; they can act as catalysts for innovation and engagement in opportunities for ongoing public health resulting in better quality of life and accelerating progress, which consist of a tangible legacy that outlasts each event. ${ }^{12,14}$ Improvement for the health care system infrastructure can occur as well as the creation of risk management strategies that will result in a legacy for planning and care of the community. ${ }^{15}$ Apart from its role in the detection of transmissible diseases, and in regulation and sanitary inspection of water and food, public health surveillance systems can also assist in early warning for threats of non-communicable diseases, such as the criminal use of chemical, biological, or radiological agents, and environmental hazards causing diseases such as those related to extreme temperatures.

These improvements for the health care system have been proposed in four areas by the World Health Organization (WHO; Geneva, Switzerland): (1) improved medical and hospital services; (2) strengthened public health system; (3) increased health awareness; and (4) enhanced living environment. ${ }^{7}$

\section{Process}

Brazilian Preparation for the World Cup 2014

The Brazilian National Policy established in 2013 defined responsibilities for the health care system and guidelines for planning, execution, and evaluation of health surveillance and emergency care during this important event. Prevention and mitigation of risks were the focus of this policy through the establishment of mechanisms of control and coordination based on health protection, promotion, surveillance, and care for this mass gathering. ${ }^{16}$ This policy was based on the premise that to offer sanitary services and security to tourists and the general population, investments are required in the education of health professionals. In particular, to implement information and communication resources to monitor and respond to public health emergency situations during these events and to increase the qualification of emergency services. ${ }^{10}$

In Brazil, the Ministry of Sports (Brasilia-DF) promoted the development of projects in the host cities to identify actions, projects, and constructions developed to prepare for the World Cup in the areas of airports, arenas, energy, urban mobility, security, telecommunications, tourism, and health.

Legacy planning was based on the idea that every mass gathering is an opportunity for health legacy and the public health component is central, as well as the ability to measure impacts of interventions, requiring collection of data around a specific indicator before and after the mass gathering. ${ }^{17}$

\section{The Process Adopted by the Host City of Porto Alegre for Developing Legacy}

For the organization and preparation of public health services, the World Cup Coordinating Committee established a Local Organizing Committee and a Thematic Chamber for Health. The Thematic Chamber was responsible for developing an Operative Plan for Emergencies and Contingency, integrating actions under the responsibility of the Ministry of Health, to be developed by the National Health Surveillance Service (ANVISA; Brasília-DF), the State Health Secretariat, the Coordination of Emergency Services and Transport, the State Health Surveillance Centre (CEVS), and Health Secretariat of Porto Alegre. This group also worked with relevant national, state, and local public and private organizations.

The first phase of the method consisted of the establishment of criteria to identify, classify, and evaluate legacy. These criteria were developed by groups of specialists of the Federal University of Rio Grande do Sul (Porto Alegre, Brazil) in each strategic area. Secondary data, documents, and official sites of the World Cup (federal, state, and local) were searched, and a literature review was conducted to identify actions and projects used to prepare for previous mass gatherings. In addition, another review was undertaken to describe legacy and to understand the necessary elements provided to support them. PubMed (National Center for Biotechnology Information; Bethesda, Maryland USA), Google Scholar (Google; Mountain View, California USA), Lilacs (Latin American and Caribbean Health Sciences Information Center; São Paulo - SP, Brazil), and Scielo (Scientific Electronic Library Online; São Paulo - SP, Brazil) were searched for Portuguese, Spanish, and English manuscripts using the terms: mass gatherings and legacy, mass gatherings and surveillance, mass gathering and public health, mass gathering and public health emergency, mass gatherings and sports, mass gatherings and health legacy, mass gatherings and safety issues, mass gatherings and large events, and mass gatherings and health care team. Examination of web sites of relevant stakeholder organizations, such as the WHO, the Health Protection Agency (HPA; London, England), the REACT project of the Robert Koch Institute (Berlin, Germany), the Centers of Disease Control and Protection (CDC; Atlanta, Georgia USA), the Brazilian Health Ministry, and official 
World Cup 2014 sites, were used to identify key documents. Lastly, Brazilian federal, state, and local legislation for health surveillance, emergency care, mass gatherings, and disaster response were also assessed.

A common structure was developed by the coordinating team, with the use of spreadsheets, in order to instruct participating areas on what information should be collected. Information gathered from literature and direct communication with recognized experts in the field were used to fill up two formularies used to identify projects, actions, and constructions from health and surveillance services perspectives. Key informant interviews were also conducted with representatives of the Municipality and State Health Secretariats to identify the stage of development of projects and proposed actions.

Meetings with representatives of the theme chambers, city and state secretariats, and public-private businesses enrolled with the projects for the World Cup were used as resources for the development of legacies. The outcomes of these meetings were discussed among the health group and the coordinating project team, and they were presented to the State Board representing the Health Sector within government for these procedures to be validated.

Each aspect of the legacies was evaluated following the previous established concepts. Legacy was considered "the material and non-material effects produced directly or indirectly by the sporting event, planned or not, that change in a permanent way the region that hosts it in an objective, subjective, positive, or negative way." 18 In addition, "the structures and results produced, directly or indirectly, for the development of mass gatherings, at national and regional level, tangible or intangible, planned or identified in the process, which transform in a permanent way the host society." ${ }^{19}$ Definitions for typology are presented in Table 1.

According to their relation with the World Cup, legacies were classified as planned before or identified along the process. This classification identified if the project/action/construction was planned to be developed in the city not depending on the existence of the World Cup or if it was identified as a need during the process of preparation.

Legacies were classified as tangible, meaning susceptible to cost-analysis evaluation, or intangible, expressing subjective impressions to be confirmed by means of qualitative research. Three dimensions were adopted: essential (infrastructure and services); public policies and citizenship rights; and innovation opportunities and business (Table 2).

For each legacy, territory coverage was evaluated as local, state, national, or international. Estimation of possible impacts introduced by the projects was evaluated as positive or negative. Successful positive actions were assessed to maximize the potential impact, whereas mitigating actions were used to diminish the impact of the negative ones. An example of the classification adopted is presented in Table 3.

\section{Discussion}

The identified legacies consist of a strengthening of public health policies and services to the Brazilian community, with augmentation of public health surveillance and workforce infrastructure and coordination mechanisms. Such benefits have been identified when planning for the Hajj, which has resulted in an advanced health care system and a pluralistic approach to public health. ${ }^{10}$

The World Cup in Brazil posed challenges for infectious diseases control due to the increase in population and population

\begin{tabular}{|l|l|}
\hline Typology & Definition \\
\hline Infrastructure & $\begin{array}{c}\text { Modernization and upgrade of the local } \\
\text { infrastructure, not directly related to the event, } \\
\text { that remains as a benefit to the society after it. }\end{array}$ \\
\hline $\begin{array}{c}\text { Citizenship } \\
\text { Rights }\end{array}$ & $\begin{array}{l}\text { Direct and indirect improvements in education } \\
\text { (non-sportive), health, security, and defense; } \\
\text { employability; and citizen basic rights. }\end{array}$ \\
\hline Economic & $\begin{array}{l}\text { Actions to appreciation of citizenship and racial, } \\
\text { ethnical, and cultural diversity. }\end{array}$ \\
\hline $\begin{array}{l}\text { Actions to foster the economic development } \\
\text { from opportunities, boosted by the generation } \\
\text { of innovative business, products, and } \\
\text { services. They include partnerships between } \\
\text { private and public sectors, the sustainable } \\
\text { development, the improvement of the } \\
\text { population quality of life, and alterations in the } \\
\text { economic structure. }\end{array}$ \\
\hline Political & $\begin{array}{l}\text { Innovations or the improvement of the } \\
\text { government model to the integration and } \\
\text { articulation between the three levels of } \\
\text { government and the civil society, to reach } \\
\text { common goals, by means of dialogue, } \\
\text { conciliation, and collaboration, using a } \\
\text { transparent process. }\end{array}$ \\
\hline Witt @ 2015 Prehospital and Disaster Medicine
\end{tabular}

Table 1. Definitions Used to Classify the Legacy According to Typology

movement ${ }^{20}$ from the event having 12 host cities. In Porto Alegre, the World Cup represented an enormous challenge where no previous event of this size was hosted. Preparing local health services to meet potential demands for emergency care, and to address access and transportation difficulties for patients and medical supplies, resulted in a systematic improvement in communications and health care systems. These changes lead to the development of relationships, and new efficiencies and permanent gains, within the private health sector. A similar outcome was also reported after the London Olympic Games. ${ }^{4}$

Eleven of the legacies identified were planned before the World Cup, with complementary funds being used to address both the immediate needs for the mass gathering as well as meeting longer-term requirements that would not otherwise have been addressed, resulting in improvement of public health functions. $^{21}$

The most far-reaching legacy was to develop a culture of first aid within the general population through training lay people in cardio-pulmonary resuscitation. This legacy was based on information from prior mass-gathering events of the scale of the World Cup. As spectators are at greater risk of heat-related illness, acute cardiac emergencies, and respiratory events, this initiative was important and contributed to the success of the event. ${ }^{22}$

\section{Study Limitations}

The proximity to the World Cup allowed for the development of a methodology applied to identify, classify, and evaluate the legacies projected for the host city of Porto Alegre. This methodology can be followed by others but may not obtain the same response. Actual benefits are only estimated with the use of the indicators developed, but further studies are needed to confirm their status as 


\begin{tabular}{|c|c|}
\hline Typology & Legacy \\
\hline \multirow[t]{2}{*}{ Infrastructure } & $\begin{array}{l}\text { Existence of a Surveillance Information System } \\
\text { computerized and monitored in real time. }\end{array}$ \\
\hline & $\begin{array}{l}\text { Acquisition of permanent equipment and } \\
\text { medical care provisions. }\end{array}$ \\
\hline \multirow[t]{4}{*}{ Sociocultural } & $\begin{array}{l}\text { Certification of food services focused on } \\
\text { regional food restaurants as grilled chicken } \\
\text { and steakhouses. }\end{array}$ \\
\hline & $\begin{array}{l}\text { Health promotion initiatives available in places } \\
\text { with large circulation of public from the event, } \\
\text { trilingual, informing health risks, and directions } \\
\text { for assistance. }\end{array}$ \\
\hline & $\begin{array}{l}\text { Establishment of a public health emergency } \\
\text { plan for the airport, integrating all the public } \\
\text { and private involved stakeholders. }\end{array}$ \\
\hline & $\begin{array}{l}\text { A notification system } 24 \text { hours, connected to } \\
\text { prepared professionals, allowing the } \\
\text { identification of emergencies in public health } \\
\text { and immediate response. }\end{array}$ \\
\hline \multirow[t]{8}{*}{ Political } & Creation of a State Force. \\
\hline & $\begin{array}{l}\text { Emergency Health Professionals prepared for } \\
\text { relief response in situations of public health } \\
\text { emergencies. }\end{array}$ \\
\hline & $\begin{array}{l}\text { Development of simulation exercises and tested } \\
\text { protocols. }\end{array}$ \\
\hline & $\begin{array}{l}\text { Development of an emergency plan for the } \\
\text { host city. }\end{array}$ \\
\hline & $\begin{array}{l}\text { Articulation between the different components } \\
\text { of the health care system. }\end{array}$ \\
\hline & Contingency plan for emergency situations. \\
\hline & $\begin{array}{l}\text { Improved management and regulation of } \\
\text { hospital beds. }\end{array}$ \\
\hline & $\begin{array}{l}\text { Organization of treatment places to meet the } \\
\text { surge demand. }\end{array}$ \\
\hline Economic & $\begin{array}{l}\text { Partnerships for capacity building in transporting } \\
\text { patients. }\end{array}$ \\
\hline $\begin{array}{l}\text { Citizenship } \\
\text { Rights }\end{array}$ & Training of laypeople in first aid. \\
\hline
\end{tabular}

Table 2. Legacy According to Typology

a legacy. Lastly, the actual impact of the legacy will be measured over time.

\section{Conclusion}

The World Cup was an opportunity for the Brazilian government to develop a specific policy regarding mass gatherings. This development allowed the government to assess and to evaluate the current available resources to provide crucial support and to build capacity for future events. In particular, the project allowed the development of a methodology for the identification, classification, and evaluation of developed health legacy in risk analysis, surveillance, mitigation measures, and provision of emergency medical care. It also allowed researchers to overview multi-sectoral

\begin{tabular}{|c|c|}
\hline Strategic Area (Theme) & Health \\
\hline $\begin{array}{l}\text { Organizations Involved (local } \\
\text { and state Health Secretariats, } \\
\text { National Agency of Health } \\
\text { Surveillance, private health } \\
\text { service, Brazilian Enterprise } \\
\text { for Airports Infrastructure } \\
\text { (INFRAERO), Civil Defense } \\
\text { Service, state police, and } \\
\text { traffic department) }\end{array}$ & $\begin{array}{l}\text { Local, state, and national health, } \\
\text { security, and traffic public } \\
\text { organizations. }\end{array}$ \\
\hline Legacies & $\begin{array}{l}\text { Inter-sectoral articulation, } \\
\text { integrated education, and an } \\
\text { emergency plan for the } \\
\text { airport. }\end{array}$ \\
\hline Dimension & $\begin{array}{l}\text { Public policy and citizenship } \\
\text { rights. }\end{array}$ \\
\hline Typology & Political. \\
\hline $\begin{array}{l}\text { Planned or Identified Along the } \\
\text { Process }\end{array}$ & Identified along the process. \\
\hline Tangible or Intangible & Tangible. \\
\hline Territorial Coverage & State. \\
\hline Situation Before the World Cup & $\begin{array}{l}\text { There were no active plans at } \\
\text { airports for coordinated health } \\
\text { responses, and no } \\
\text { accompanying protocols. }\end{array}$ \\
\hline Situation After the World Cup & $\begin{array}{l}\text { A contingency plan was } \\
\text { developed integrating medical } \\
\text { agencies based at the airport } \\
\text { with existing public health } \\
\text { services through the } \\
\text { development of integrated } \\
\text { simulations. }\end{array}$ \\
\hline Possible Impacts & $\begin{array}{l}\text { Consolidation of an intra- and } \\
\text { inter-sectoral action and } \\
\text { improvement of response in } \\
\text { emergency situations. }\end{array}$ \\
\hline Positive or Negative & Positive. \\
\hline Mitigate or Potentiating Actions & $\begin{array}{l}\text { Keep updated roaster of } \\
\text { professionals and perform } \\
\text { continued education, develop } \\
\text { simulations more frequently, } \\
\text { alternating situations and } \\
\text { institutions. }\end{array}$ \\
\hline Evaluation Indicators & Non applicable. \\
\hline Type of Indicators & Non applicable. \\
\hline
\end{tabular}

Table 3. Application of the Developed Classification to One of the Legacies

preparation which included security, military, civil defense, and public communication actions, the event's organizers and constituents, as well as other international partners.

Data collected for the project can support future legacy research through a framework on the four areas of health system improvement as proposed by the WHO. Beyond the experience for preparing for future events, the identified legacies seem to 
represent a considerable improvement of health surveillance and services. The application of the methodology with the evaluation of legacies with the developed indicators will allow the knowledge of in what dimension the Brazilian population will have the opportunity to benefit from this event for times to come.

\section{References}

1. Arbon P. Planning medical coverage for mass gatherings in Australia: what we currently know. J Emerg Med. 2005;31(4):346-358.

2. Gerstel L, El Omeiri N, Valenciano M, Moren A. Epi concept: challenges and lessons learned in preparing for mass gatherings: a literature review. December 2009. Commissioned by the European Center for Disease Prevention and Control (ECDC). Contract $n^{\circ}$ OJ/2008/02/29-PROC/2008/004. Available upon request from the ECDC Web site. http://ecdc.europa.eu/en/Pages/home.aspx. Accessed November 2014.

3. Massuda A. Megaeventos no Brasil: oportunidades e desafios da copa do mundo FIFA 2014 para o Sistema Único de Saúde. Rev. Bras. Cardiol. 2012;25(5):358-361.

4. Black G, Kononovas K, Taylor J, Raine R. Health care planning for the Olympics in London: a qualitative evaluation. PLoS ONE. 2014;9(3):1-6.

5. World Health Organization. The Health Legacy of the 2008 Beijing Olympic Games: Successes and Recommendations. Dapeng J, Ljungqvist A, Tro H, (eds). Philippines: WHO Western Pacific Region Publication; 2010. http://www.olympic.org/ documents/commissions_pdffiles/medical_commission/the_health_legacy_of_the_2008 beijing_olympic_games.pdf. Accessed November 2014.

6. Mass gathering health - creating a public health legacy (Editorial). Lancet. 2012;380 (9835):1.

7. World Health Organization. Communicable disease alert and response for mass gatherings. WHO Web site. http://www.who.int/csr/mass_gathering/en/. Published 2008. Accessed November 2014.

8. Milstein A, Seaman K, Liu P, Bissell R, Maguire B. Variables influencing medical usage rates, injury patterns, and levels of care for mass gatherings. Prehosp Disaster Med. 2003;18(4):334-346.

9. Lombardo JS, Sneigoski CA, Loschen WA, et al. Public health Surveillance for mass gatherings. Johns Hopkins APL Technical Digest. 2008;27(4):347-355.

10. Memish ZA, Stephens GM, Steffen R, Ahmed QA. Emergence of medicine for mass gatherings: lessons from the Hajj. Lancet Infect Dis. 2012;12(1):56-65.

11. Yi H, Zheng'an Y, Fan W, et al. Public health preparedness for the world's largest mass gathering: World Exposition in Shanghai, China. Prehosp Disaster Med. 2010; 27(6):589-594.

\section{Acknowledgement}

The authors would like to thank Brazilian Conselho Nacional de Pesquisa e Desenvolvimento - CNPq for the concession of research scholarships (Process \#400053/2013-6) for the development of this project.

12. Thackway S, Churches T, Fizzell J, Muscatello D, Armstrong P. Should cities hosting mass gatherings invest in public health surveillance and planning? Reflections from a decade of mass gatherings in Sydney, Australia. BMC Publ Hlth. 2009;9(324):1-10.

13. Shoaf K, Castro CGSO, Miranda ES. Hospital preparedness in advance of the 2014 FIFA World Cup in Brazil. Prehosp Disaster Med. 2014;29(4):409-416.

14. Rodrigues RP, Pinto LMM, Terra R, Costa LP, (Orgs). Legados de Megaeventos Esportivos. Brasília, DF, Brazil: Ministério dos Esportes; 2008.

15. Santos R. Gestão de desastres e política de assistência social: estudo de caso de Blumenau/SC. https://repositorio.ufsc.br/bitstream/handle/123456789/99485/309487. pdf?sequence=1. Published 2012. Accessed November 2014.

16. Brasil Ministério da Saúde. Portaria $n^{\circ} 1.139$, de 10 de junho de 2013. Define, no âmbito do Sistema único de Saúde (SUS), as responsabilidades das esferas de gestão e estabelece as Diretrizes Nacionais para Planejamento, Execução e Avaliação das Ações de Vigilância e Assistência à Saúde em Eventos de Massa. http://bvsms.saude.gov.br/bvs/saudelegis/ gm/2013/prt1139_10_06_2013.html. Published 2013. Accessed November 2014.

17. Barbeschi M, Isla N, Davis S, Nunn M. Framing mass gatherings as a new discipline a modern paideia. Presentation at: Lancet Conferences: Mass Gathering Medicine. October 2010; Jekkah, Kingdom of Saudi Arabia.

18. Chappelet JL, Junod T. "A tale of 3 Olympic cities: what can Turin learn from the Olympic legacy of other Alpine cities?” In: Torres D, (ed). Major Sport Events as Opportunity for Development, Proceedings of the Valencia Summit. Valencia: Instituto Nóos; 2006: 83-89.

19. DaCosta L, Corrêa D, Rizzuti E, Villano B, Miragaya A. Legados de Megaeventos Esportivos. Brasilia: Ministério do Esporte; 2008.

20. Schenkdel K, Williams C, Eckmanns T, et al. Enhanced surveillance of infectious diseases: the 2006 FIFA World Cup experience, Germany. Euro Surveil. 2010; 11(12):234-239.

21. World Health Organization. Mass gatherings and public health. http://www.euro. who.int/_data/assets/pdf_file/0009/98415/E90712.pdf. Published 2004. Accessed November 2014.

22. Yancey II AH, Fuhri PD, Pillay Y, Greenwald I. World Cup 2010 planning: an integration of public health and medical systems. Public Health. 2008;(122):1020-1029. 